\title{
CHARACTERISTICS AND PRINCIPLES OF RESOURCE-ORIENTED TEACHING
}

\author{
Olena Shtepa \\ Ivan Franko National University of Lviv \\ Department of Psychology \\ 41 Doroshenko St., Office 1, Lviv 79000 Ukraine \\ e-mail: o_shtepa@lnu.edu.ua
}

\begin{abstract}
ABSTACT
This article addresses the problem of professional training of future psychologists. It is assumed that it is possible to find an optimal correlation between the acquisition of special knowledge and the formation of personal readiness of psychologists for professional activity. As demonstrated in the article, the character of this correlation depends on the use of a specific method of teaching, and more specifically, the conception of teaching oriented towards forming certain personal qualities. For the efficient education of psychologists it is necessary to make a systemic analysis of expected personal changes in the process and as a result of teaching them. In theory we are realizing an analysis of expected personal changes in the process and the result of teaching them in following modern conceptions of teaching: of programmed teaching, of problem-based teaching, of euristic teaching, of developing teaching, of media-education, of interactive teaching, of active social and psychological teaching, of person-oriented teaching, of experiential teaching. In this paper the author analyzes the main principles of resource-oriented teaching. Resource-oriented teaching creates the ground for the optimal combination of the requirements of professional preparation and personal development of psychology students.
\end{abstract}

Keywords: conception of teaching, personal readiness for professional activity, resources, professional conception of teaching of psychologist

\section{INTRODUCTION}

Efficient training of future specialists involves two components, special knowledge and personal readiness for professional activity. A philosophical consideration of the phenomenon of specialist's readiness shows that the afore-mentioned two-component structure may cause the conflict of priorities between the high level of knowledgeability and the development of professional qualities of a future professional. The problem of correlation between professional knowledgeability and personal readiness is specifically manifested in the context of educating future psychologists, for whose profession personality is the main tool. According to Tatyana Yatsenko (2006, pp. 5-12, 31), "preparation of psychologists(. . . ) is characterized by a division of psychological cognition and self-cognition". 
It seems logical to address the question of the correlation of knowledge and personal qualities of a future professional in the context of pedagogical psychology since its subject embraces personal changes in the process, and as a result of, teaching and upbringing, both of which, in turn, result from the external influence (Kazanskaya, 2003, p. 11).

We consider it possible to solve the above signaled problem by finding an optimal correlation between the acquisition of special knowledge and the formation of personal readiness of psychologists for professional activity. The character of that correlation is contingent on the application of a specific teaching method, here specifically the method of teaching oriented at foregrounding certain personal qualities.

To elucidate the concept of efficient preparation of psychologists, it is necessary to make a systemic analysis of expected personal changes in the process and as a result of teaching. The aim of the theoretical discussion that follows is to review some of the modern conceptions of teaching and to point out the principles of resource-oriented teaching.

\section{RESULTS}

The relevance of the study is to describe the concepts, systems training, the application of which is formed such as personality as resourcefulness. We believe that personality resourcefulness is professionally important quality for future psychologists.

Scientific novelty of the research is determined by the context of the analysis of personality changes in the process and outcome of learning. Namely possible personality changes are considered from the perspective resourcefulness man, that is integrative personal qualities, and not unconditionally criteria of knowledge and skills. The theoretical significance of the research is to demonetization principles of effective professional learning of students-psychologists.

The purpose of the study description of the principles of the concept of learning, which allows you to create professionally important personal qualities.

The paradigm of the studies is humanistic. When considering the personality changes that occur with the student in the process and the result of his training, in accordance with the humanistic paradigm, we relied on the principles of personal integrity, its ability to self-determination, proactive personality, nonlinearity development. The main condition for the development of the individual under consideration the human need to be understood and accepted, as well as its demand for a life of meaning and realization of personal potential.

The study of the vocational training system. Subject of research - qualities of personality that are generated or updated as a result of the application of those or other learning systems. Methods of theoretical research: analysis method to characterize the personality changes in the process and the result of applying one or another system of education, the method of discourse analysis to positioning the concept of resource-oriented training in the system other concept learning method traduccio for quality to characterize position concepts of resource-oriented train- 
ing in the coordinates of constructivism and discursivity, comprehensive method and the method of conceptualization to characterize the principles of the concept of resource-oriented training.

In particular, a form of realization of conceptions of applied active social and psychological and experiential teaching is social and psychological awareness training (in learning and psychotherapeutic groups), while person-oriented teaching is realized through teaching practice (a class, lecture, seminar), individual and experimental tasks (individual project, scientific work) or individual work with a pupil/student (conversation). Such a combination of academic forms of teaching and trainings of personal development for psychology students is effective in its own way, but such an approach does not resolve the problem of the incompatibility between professional knowledgeability and personal readiness.

Teaching in which the outcome of pupils' learning is pre-determined, free interpretation of facts is impossible, subjectivity is considered false and the teacher has a controlling and stimulating function is called "directivity of knowledge". Teaching presupposing a two-layer system of knowledge (facts and their interpretation), which places emphasis on pupils' motivation for generating new knowledge, recognizing the significance of the author's position towards teaching information is discoursive. This 'discoursiveness of knowledge' manifests itself in valuing personality which generates knowledge.

In our view, personal readiness of psychology students can be achieved if they are trained according to principles of constructivist-discoursive direction. For this reason, resource-oriented teaching is positioned in this segment. It is, however, necessary to describe the peculiarities of resource-oriented teaching in relation to the framework of constructivist-discoursive direction, which encompasses notions of person-oriented teaching, experiential teaching and active social and psychological teaching (Tab.1).

The above mentioned teaching methods are united by the principle of personal self-correction, as well as the reliance of the efficiency of teaching on the level of students' reflexive skills. The main difference between them is conceptual, which, in turn, leads to the different character of expected changes. Within the resourceoriented teaching paradigm, students do not only have the opportunity to aspire to self-perfection, but they can also apply their own resources as an instrument in professional activity, i.e. acquire psychological resourcefulness.

Tab. 1. Characteristics of resource-oriented method of teaching as compared with constructive-discoursive teaching.

\begin{tabular}{|c|c|c|c|c|}
\hline \multirow{2}{*}{$\begin{array}{c}\text { Criterion of } \\
\text { comparison }\end{array}$} & $\begin{array}{c}\text { Resource-oriented } \\
\text { teaching }\end{array}$ & $\begin{array}{c}\text { Person-oriented } \\
\text { teaching }\end{array}$ & $\begin{array}{c}\text { Experiential } \\
\text { teaching }\end{array}$ & $\begin{array}{c}\text { Active social and } \\
\text { psychological } \\
\text { teaching }\end{array}$ \\
\hline Main concept & Resource & Subjective experience & $\begin{array}{c}\text { Self-cognition in } \\
\text { spontaneously } \\
\text { generated model of } \\
\text { relations }\end{array}$ \\
\hline
\end{tabular}




\begin{tabular}{|c|c|c|c|c|}
\hline \multirow[b]{2}{*}{ Main principles } & \multicolumn{4}{|c|}{ Personal self-correction, and also: } \\
\hline & $\begin{array}{c}\text { Ability to } \\
\text { formulate life } \\
\text { tasks, attitudes } \\
\text { to life and } \\
\text { teaching tasks as } \\
\text { to opportunities, } \\
\text { significance of } \\
\text { co-operation with } \\
\text { others }\end{array}$ & $\begin{array}{l}\text { Recognition of } \\
\text { life experience } \\
\text { as personally } \\
\text { significant and } \\
\text { unique; finding } \\
\text { peculiarities } \\
\text { of subjective } \\
\text { experience and } \\
\text { using them in } \\
\text { teaching/learning; } \\
\text { modification } \\
\text { and organization } \\
\text { of subjective } \\
\text { experience } \\
\end{array}$ & $\begin{array}{l}\text { Life experience } \\
\text { concerning } \\
\text { certain } \\
\text { problems; } \\
\text { reflection on } \\
\text { one's own } \\
\text { experience; } \\
\text { self-change }\end{array}$ & $\begin{array}{l}\text { Reflexive self- } \\
\text { cognition; mutual } \\
\text { help; objective } \\
\text { perception of social } \\
\text { reality }\end{array}$ \\
\hline $\begin{array}{l}\text { View updated } \\
\text { competence }\end{array}$ & General & Life & Psychological & Communicative \\
\hline \multirow{2}{*}{$\begin{array}{l}\text { Criterion } \\
\text { of personal } \\
\text { readiness } \\
\text { of student } \\
\text { for learning } \\
\text { according to a } \\
\text { given model }\end{array}$} & \multicolumn{4}{|c|}{ Reflective skill, and also: } \\
\hline & $\begin{array}{l}\text { Abilities of self- } \\
\text { analysis and self- } \\
\text { organization }\end{array}$ & $\begin{array}{l}\text { Abilities of setting } \\
\text { goals and self- } \\
\text { efficiency }\end{array}$ & $\begin{array}{l}\text { Abilities of } \\
\text { self-analysis } \\
\text { and self- } \\
\text { motivation }\end{array}$ & $\begin{array}{l}\text { Tolerance to others } \\
\text { and ability to co- } \\
\text { operate }\end{array}$ \\
\hline $\begin{array}{l}\text { Character } \\
\text { of expected } \\
\text { personal } \\
\text { changes }\end{array}$ & $\begin{array}{c}\text { Ability to use } \\
\text { own experience } \\
\text { for helping others }\end{array}$ & $\begin{array}{l}\text { Personal self- } \\
\text { development }\end{array}$ & Self-perfection & Personal correctness \\
\hline $\begin{array}{l}\text { forms of } \\
\text { education }\end{array}$ & \multicolumn{2}{|c|}{$\begin{array}{l}\text { Learning the lesson (lesson, lecture, } \\
\text { seminar), individual research } \\
\text { assignment (individual project, } \\
\text { scientific work) individual work with a } \\
\text { student/student (talk) }\end{array}$} & & \\
\hline \multirow{2}{*}{$\begin{array}{c}\text { Criteria of } \\
\text { valuation of } \\
\text { the acquired } \\
\text { knowledge and } \\
\text { skills }\end{array}$} & \multicolumn{4}{|c|}{$\begin{array}{c}\text { Ability to analyze, synthesize information and to provide one's own } \\
\text { assessment with regard to: }\end{array}$} \\
\hline & \multicolumn{2}{|c|}{$\begin{array}{l}\text { One's own characteristics and } \\
\text { existential possibilities }\end{array}$} & & \\
\hline $\begin{array}{l}\text { The content of } \\
\text { the feedback } \\
\text { from the } \\
\text { teacher/ } \\
\text { lecturer to } \\
\text { pupils/ } \\
\text { students }\end{array}$ & \multicolumn{2}{|c|}{$\begin{array}{c}\text { Focusing on the unique qualities } \\
\text { of a person, which allows to solve } \\
\text { successfully tasks successfully, as well } \\
\text { as on the importance of cooperation, in } \\
\text { which they were opened }\end{array}$} & & \\
\hline \multirow{2}{*}{$\begin{array}{c}\text { Indicators } \\
\text { of personal } \\
\text { readiness of the } \\
\text { teacher to the } \\
\text { application of } \\
\text { the concept of } \\
\text { learning }\end{array}$} & \multicolumn{4}{|c|}{ The ability to effectively motivate, and also: } \\
\hline & $\begin{array}{l}\text { the ability to self- } \\
\text { opening }\end{array}$ & & & \\
\hline
\end{tabular}

Source: Own chart. 
In order to achieve the expected results within the resource-oriented conceptionmodel, it is necessary to apply follow certain constructivist principles. Below we have formulated the following principles of resource-oriented teaching.

Shaping students' sense of opportunity. It is necessary to encourage creative solutions with regard to teaching tasks, i.e. motivate students to go beyond wellestablished frames, favour the formation of abilities to justify their decisions or provide answers to students' equiries based not only on the teacher's knowledge, but also their own experience.

To form and update students' psychological, communicative and general competence. While specifying and evaluating the student's work, it is necessary to place emphasis on unique features of its author and his/her self-development and self-organization for achieving the learning goal. To show/explain students how their competence was being formed: what has been learned with the help of other authors and fellow students, and what is the result of their own experience.

Developing students' skill of self-management. It is advisable to familiarize students with methods of self-management and encourage their application in performing learning tasks. It is necessary to show how the knowledge and application of self-organization methods helps in achieving success and realizing life goals.

Reinforcement of students' ability to analyze their own record of successes and failures. While studying scientific theories, students' attention should be drawn to the personalities of the creators of these ideas, to the way those authors achieved success, and how they went through failures and managed to gather themselves. It is important to characterize the influence and an axiological importance of scientists' ideas for the development of science and human history. To favour the formation of students' moral intention, which will help them form their attitude towards successes and failures concerning the main values.

Inculcating upon students the need to co-operate. It is important to demonstrate that co-operation is a way of learning from others. It is recommendable to help students realize that the character of influence of other people on their personality may be different, but only they themselves should decide what should be learnt from those people. To motivate students to value the experience of communicating with others. To draw their attention to the personal responsibility of accepting or rejecting the influences of others and their own influence on the environment. It is important to single out the unique rather than competitive qualities of students. It is important to show how achieving learning goals and self-development goals may affect one's personality and the relations with others, namely, if s/he is ready to collaborate with others or builds competitive relations, if $\mathrm{s} / \mathrm{he}$ is altruistic or manifests machiavellism.

Formation of students' aspiration of self-development. It is important to organize psychological accompaniment of students for their formation of learning and scientific challenges as life tasks, i.e. tasks of self-development. To encourage students to choose their way of resolving tasks or achieving learning goals in order to make decisions based on moral principles. To encourage students to formulate life tasks as self-development tasks. To encourage their aspiration and ability to make independent choices and take responsibility for them. To help students see different ways of achieving goals based on moral principles. 
In our view, the capability of applying resource-oriented teaching in the classroom depends on the teacher's ability for self-development, readiness for self-realization and ability to motivate students.

\section{DISCUSSION}

The analysis of theoretical resources enabled us to distinguish the following modern models of teaching: programmed teaching, problem-based teaching, euristic teaching, developing teaching, media education, interactive teaching, active social and psychological teaching, person-oriented teaching and experiential teaching. Each of these models was analyzed in order to assess to what extent it shows the correlation between knowledgeability and personal changes. Accordingly, the assumptions of the expected personal changes were expressed. In doing so, the akmeological interpretation of the principle of development was used (Derkach, 2003, p. 32), which characterizes development as progress. This is why the expected personal changes were interpreted as positive.

The main principles of programmed teaching are the algorithmic organization of teaching, setting the tasks for monitoring the correctness of the acquisition of knowledge, instructing pupils on the next step in their learning depending on the correctness of their answers (Yagupov, 2006). Within this paradigm, the character of correlation between knowledgeability and personal readiness is characterized by the increase in the amount of pupils/students' knowledge. The expected personal changes may include increased readiness to trust the teacher to manage the process of teaching/learning.

Problem-based teaching in the first place aims at endorsing creativity, interest in learning, independence in solving problematic learning tasks of different types (Yagupov, 2006). Within this framework, the correlation between knowledgeability and personal readiness gains the character of a connection between basic knowledge and autonomy of a personal autonomy in learning. The expected personal changes may that pupils/students are more self-motivated and have an internally organized motivation.

The media-education model relies primarily on teaching theory and developing practical skills of mastering modern mass communication media, forming pupils/students' competences of media literacy, evaluation competence, development of aesthetic perception and taste (Naidionova, \& Boryshpolets, 2010, pp. 285-293). The character of correlation between knowledgeability and personal readiness within this paradigm manifests itself in catalyzing the influence of information on a person's decision-making. Expected personal changes may include the formation of pupils/students' critical thinking.

The concept of developing teaching is based on the principles of dominating theoretical knowledge, teaching on the high level of complexity, reflecting on the process of learning, quick tempo of learning (Khutorskoy, 2004, pp. 234-245, 257). Within this conception of teaching the correlation between knowledge ability and personal readiness has an accord character. Expected changes include the formation of pupils/students' self-determination. 
Euristic teaching aims at promoting the pupil's subjective knowledge, construing personal sense, aims and content of learning (Khutorskoy, 2004). Within this paradigm, the correlation between knowledgeability and personal readiness has a character ofpoints to the dependence of the result of learning on the feeling of personal influence. Expected personal changes are the formation of general competence of pupils/students and their inner locus of control.

Interactive teaching is characterized by the principle of teaching in a dialogic interaction. The main condition of the efficiency of interaction is the parity between teacher and pupils (Galitsyna, 2005, pp. 30-32). According to this model, the correlation between knowledgeability and personal readiness has a character of underscores the dependence of the efficiency of learning on the pupils/ students' ability to co-operate. Expected personal changes may be the formation pupils/students' communicative competence and tolerance.

The model of active social and psychological teaching has been developed to train professional psychologists. The essence of this kind of teaching lies in its potential to provide future professionals with the ability to objectively perceive social-perceptive material in communicative situations; it enables them to learn either to accept or reject decisions suggested by others, study existing problems and distinguish them from imaginary ones, help each other in the field of mutual understanding and personal development (Yatsenko, 2006). Within this conception personal readiness dominates in conjunction with knowledgeability so that personal changes become priority, which are possible if students' ability of reflection and self-analysis is formed. Expected personal changes include the formation of students' self-acceptance and readiness for self-revelation, which, according to T. Yatsenko's (2006) understanding, means the results of personal self-correction.

The main tenets of person-oriented teaching are the following: pupil/studen$t^{\prime}$ s awareness of their own experience, expression of their own positions towards fundamental achievements of humanity, recognition by the teacher and pupils/ students of uniqueness and individual intrinsic value of every human being (Khutorskoy, 2004). Within person-oriented teaching, the correlation between knowledgeability and personal readiness is dominated by personal changes, which are possible if the teacher supports pupils/students' self-interest and refreshes their subjective experience. Expected personal changes include the formation of pupils/students' humanistic life principles and motivation of their personal self-development.

Some of the distinctive aspects of experiential teaching are: personal experience, reflection of life experience, and, as a result, the transformation/modification of knowledge and personal views. One gets the opportunity to analyze their own negative and positive life experiences and, in the experience of themselves and others, find the most individually efficient ways of action (Burnard, 2002, pp. 26-27). Within this model, the correlation between knowledgeability and personal readiness is dominated by personal changes, which are possible when the teacher actualizes motivation to self-cognition and self-change. Expected personal changes include the formation of pupils/students' readiness for self-perfection. 
Each of the discussed teaching framworks may be effective if when applied in psychology teaching. However, the models giving priority to personal readiness attract more attention. This is why we may state that the most effective approaches to teaching psychology students are active social-psychological teaching, person-oriented teaching and experiential teaching.

Therefore, it is necessary to underscore the necessity of developing the model of teaching that will enable future psychologists to reflect on their own professional readiness. This, according to Natasha Mykhalchuk (2011, pp. 385-389), will result in the creation of a psychologist's individual experience (Mykhalchuk, 2011). Researchers interpret such personal experience "as the experience of being oneself... a person feels able only through accepting own individuality, - to realize own uniqueness, own potential" (Rogers, cited by: Trach, Ball, 2001, pp. 38-39). The possibility of acquiring specific experience by a psychologist is connected with the actualization of psychological resources of self-development (Kuzikova, 2012, pp. 132-139).

The review of literature (Kalashnikova, 2001, pp. 185-189; Petrovsky, 2008, pp. 77-100; Frank, 2000, p. 868) allows to integrate the characteristics of resource as "inner fund" of a personality, i.e. spiritual abilities which are experienced as a measure of realizability of his/her needs.

Thus, the resource may be described as a concept which will define the attributes of efficient conception of teaching psychologists, the conception of resource-oriented teaching.

With the aim of characterizing the conception of resource-oriented teaching as the system of preparation efficient for psychologists, modern conceptions of teaching have been systemized. The criteria for systemic description include peculiarities of subjects of teaching and process of teaching. The vectors of typology of conceptions are "orientation ontopersonalities of a teacher/pupil" and "directivity - discoursiveness of knowledge" (Fig. 1).

In characterizing the vector "orientation onto personalities of a teacher/pupil", we relied on the views of Guy Lefrancois (2005, p. 26), an American pedagogical psychologist, who analyzes directive and constructivist models of teaching. The former is characterized by the expectation that the advantage of informing, evaluation and determining the aims should be the teacher's priority. The constructivist model of teaching, on the other hand, gives these priorities to the pupil.

Conclusions and perspectives of research suggestions for future research. The article is theoretically analyzed the resource-oriented concepts with students. Determined position of resource-oriented training concepts in the coordinates of constructivism and discursivity. Describe the main principles of the author's concept of resource-oriented training concepts. The theoretical study was the characterization of the resource-oriented training concepts such as what is affecting for the formation of personality of students ' readiness to professional activities. We believe that the use in the training of students-psychologists resource-oriented training concepts actualizes their personal resources and, thus, creates the preconditions for the formation of their personal readiness in future professional activity. The application of the resource-oriented training concepts it is possible to realize 


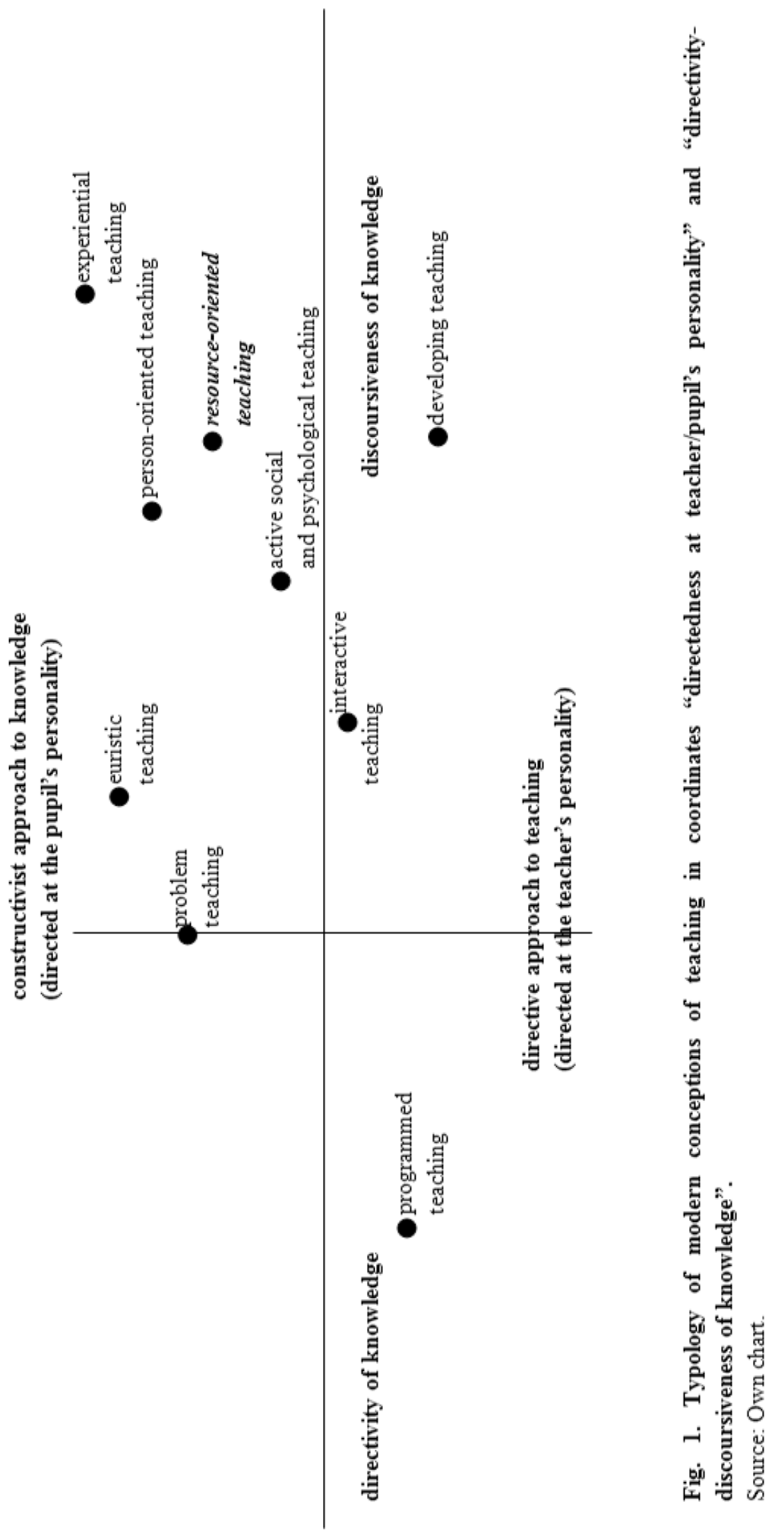


the main goals of professional training - professional competence and personal readiness, because it is in line with this concept, students develop a personal experience in solving professional problems. The way the organization presents the concept of learning is the application of the stated principles of resource-oriented teaching. In the future we plan description of the empirical validation of the effectiveness of resource-oriented training concepts.

\section{REFERENCES}

Burnard, F. (2002). Тренинг межличностного взаимодействия [Training of interpersonal interaction]. Санкт-Петербург: Питер.

Derkach, A. (2003). Акмеология[Psychology]. Санкт-Петербург: Питер.

Galitsyna, L. (Ed.). (2005). Ігри дорослих. Інтерактивні методи навчання [Adult games. Interactive teaching methods]. загальнопедагогічних газет.

Kazanskaya, V. (2003). Педагогическая психология [Educational Psychology]. Санкт-Петербург: Питер.

Kalashnikova, S. А. (2001). Личностные ресурсы и психологическое здоровье человека: соотношение содержания понятий [Personal resources and mental health: the ratio of the content of concepts]. Гуманитарный вектор, 2(26), 185-189.

Kuzikova, S. B. (2012). Емпіричне дослідження саморозвитку суб'єктної діяльності [Empirical studies of the subjective self]. Психологічні науки: проблеми і здобутки, 6, 132-139.

Lefrancois, G. (2005). Прикладная педагогическая психология [Applied Educational Psychology]. Санкт-Петербург: Прайм-ЕВРОЗНАК.

Naidionova, L. A., Boryshpolets, O. T. (Eds.). (2010). Медіакультура особистості: соиіальнопсихологічнии підхід [Media culture of personality: social-psychological approach]. Київ: Міленіум.

Mykhalchuk, N. (2011). Розвиток особистісного досвіду майбутнього психолога під час його професійної підготовки у вищій школі [Development of personal experience future psychologist during his training in high school]. Освіта регіону: політологія, психологія, комунікації. Український науковий журнал, 3, 385-389.

Petrovsky, V. (2008). Состоятельность и рефлексия: модель четырех ресурсов [Consistency and reflection: a model of the four resources]. Психология. Журнал высшей школы экономики, 5(1), 77-100.

Trach, R., Ball, G (Eds.). (2001). Гуманістична психологія: Антологія. Том 1: Гуманістичні підходи в західній психологіï XX cm [Humanistic Psychology. Anthology. Volume 1: Humanistic approaches in Western psychology in 20 th century]. Київ: Університетське видавництво Пульсари,

Frank, S. (2000). Предмет знания. Душа человека [Subject knowledge. The soul of Man]. Мінськ: Харвест; Москва: АСТ.

Khutorskoy, A. V. (2004). Практикум по дидактике и методикам обучения [Workshop on didactics and teaching methods]. Санкт-Петербург: Питер.

Yagupov, V. V. (2006). Педагогіка [Pedagogy]. Retrieved from http://eduknigi.com/ped_view. php?id=153.

Yatsenko, T. S. (2006). Основи глибинної психокорекції: феноменологія, теорія і практика [Fundamentals of deep correction: phenomenology, theory and practice]. Київ: Вища шк 